International Journal of Social Science and Economic Research

ISSN: 2455-8834

Volume:06, Issue:05 "May 2021"

\title{
REFURBISHING A WRECKED SYSTEM OF AGRICULTURE MARKETING IN INDIA
}

\author{
Dr. K.C. Gummagolmath ${ }^{1}$ and Dr. Ashwini Darekar ${ }^{2}$ \\ ${ }^{1}$ Director (M\&E) at National Institute of Agriculture Extension Management (MANAGE), Hyderabad \\ ${ }^{2}$ Chief Consultant at National Institute of Agriculture Extension Management (MANAGE), Hyderabad \\ DOI: 10.46609/IJSSER.2021.v06i05.009 URL: https://doi.org/10.46609/IJSSER.2021.v06i05.009
}

\section{Background}

Agriculture continues to be main stay in India as more than $48 \%$ of its population is dependent on agriculture and it contributes around 13 percent to the National GDP. The agricultural production has increased over the years leading to increase in marketable surplus. Until India became self-sufficient, marketing of agricultural produce was not a challenge. However, the major challenge, especially after the year 2000 has been to find a market for the surplus and getting remunerative prices. Remunerative prices are going to be the incentive for farmers to produce more and it is going to be deciding factor for acreage for the next season. Agriculture sector, unfortunately due to several issues such as small holdings, low price realization and lack of investment is no longer alucrative enterprise.

Marketing and production of agricultural produce are intertwined with each other. In the post liberalization and globalization scenario, an effective agricultural marketing system is the key driver of the agricultural economy of a country. An ideal marketing system aims at ensuring remunerative prices to the producers on one hand and smooth supply of commodities to consumers at reasonable prices on the other hand. Well-functioning agricultural marketing systems can reduce the cost of food and the uncertainty of supply, improving the food and nutritional security of poor and non-poor households. However, due to long and multiple marketing channels, on one hand farmer is getting a minute portion of consumer rupee and on the other hand consumer ends up paying higher prices. Several studies have revealed that farmers receives only $25-40$ percent of what consumer pays in the case of vegetables $\&$ fruits. The situation is somewhat better in the case of staples where, farmer receives around $65-70$ percent of consumer rupee. Hence, there is a need evolve good marketing practices for reducing the transaction costs. By linking farmers more closely to consumers, these marketing systems will benefit both consumer and farmers. There is a need for creating ecosystem for sensitising 
International Journal of Social Science and Economic Research

ISSN: $2455-8834$

Volume:06, Issue:05 "May 2021"

the farmers on new market opportunities and guide their production to meet changing consumer preferences for quantity, quality, variety, and food safety (World Bank) ${ }^{1}$.

In this direction, from time immemorial, in order to protect the interests of the various stakeholders of the agricultural marketing system of the country, number of interventions have been taken. One such intervention has been regulation of marketing of agriculture which arose from the anxiety of the British rulers to make available supplies of pure cotton and other raw materials at a reasonable prices to the industries in their country.

In the quest of procuring raw material from India, the then British government initiated setting up of public owned wholesale regulated markets. The first such regulated Karanjia Cotton Market was established as early as in 1886 under Hyderabad Residency Order. Subsequently, the first legislation was in the form of 'Berar Cotton and Grain Market Act of 1897'. The 1897 Act became a model Act for legislation in other parts of the country. The then Bombay Government was first province to enact 'Cotton Market Act in 1927'. This was the first law in the country which attempted to regulate markets with a view to evolving fair market practices. The Royal commission on agriculture set up in 1928, and central banking enquiry committee in 1931, recommended establishment of Directorate of Marketing and Inspection under the Ministry of Food and Agriculture. Subsequently some states before independence and some states after independence enacted Agriculture Produce Marketing (APMR) Act. No doubt, the process of regulation of marketing of agricultural produce induced some good practices into the system.

\section{Importance of agriculture marketing in India}

\section{Status of Agricultural Marketing in India}

The growth in regulated markets (Figure-1) kept pace with crop production and marketable surplus till 1991 and at a moderate level till 2008 (Chand, 2012).

Regulated Markets have been playing an important role in marketing of agri-products. The establishment of regulated markets started during 1930s, but the programme got its momentum only after Independence. The first several Five Year Plans, starting in 1951, emphasized the construction of wholesale markets, storage structures and warehouses, and transport lines (Expert Committee on Agricultural Marketing, 2001, known as the 'Guru Report').

\footnotetext{
${ }^{1}$ Bringing Agriculture to Markets, World Bank,
} 
International Journal of Social Science and Economic Research

ISSN: 2455-8834

Volume:06, Issue:05 "May 2021"

Figure-1: The number of Wholesale Regulated Markets in India since independence

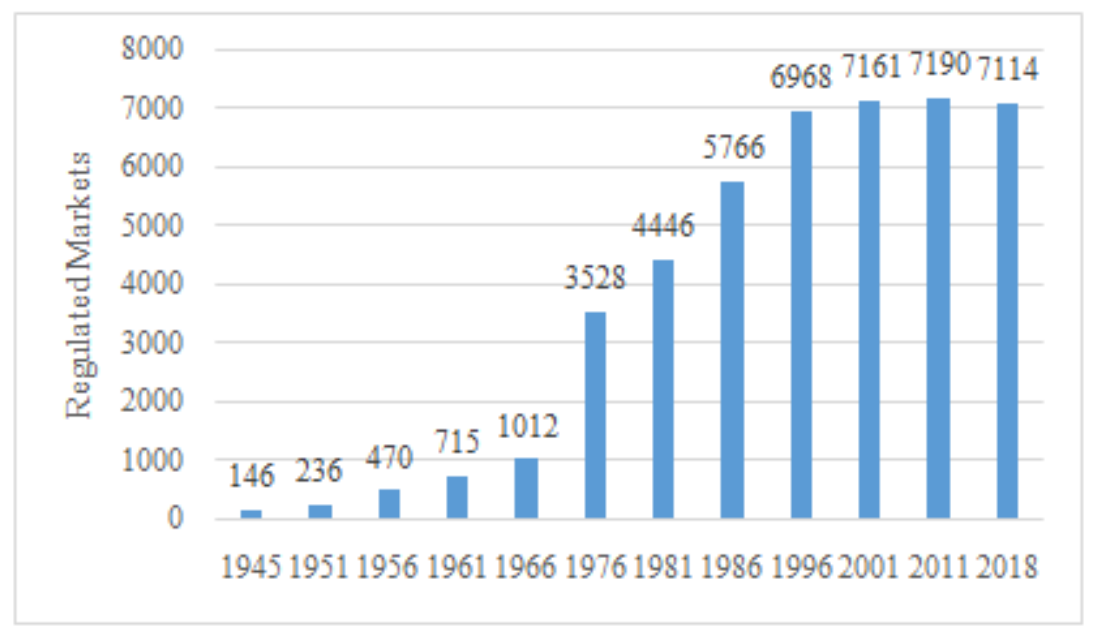

Source: https://agmarknet.nic.in

It is estimated that in 1947 -the year of India's independence - there were only 268 wholesale markets. The regulated markets have steadily grown from 286 in 1950 to 7,114 by 31 March 2018 (Figure-1). Nearly 98 per cent of the wholesale markets are now functioning under the Agriculture Produce Market Regulation Act. Between the 1960s and 1980s, most of the states and union territories adopted Agriculture Produce Market Regulation Act and established APMCs. This required that the states build and maintain the 'yards' (mandis) by using market taxes with licensed/registered (but private sector) commission agents (CAs) and licensed traders in the yards. All wholesale trade was then required to pass via the APMC yards, paying a commission to the CAs, a tax to the market (cess), as well as to off-loaders, loaders, and to 'weighing men' who registered the transaction. 
Volume:06, Issue:05 "May 2021"

Figure 1: Internal and External Drivers of Agricultural Marketing Reforms

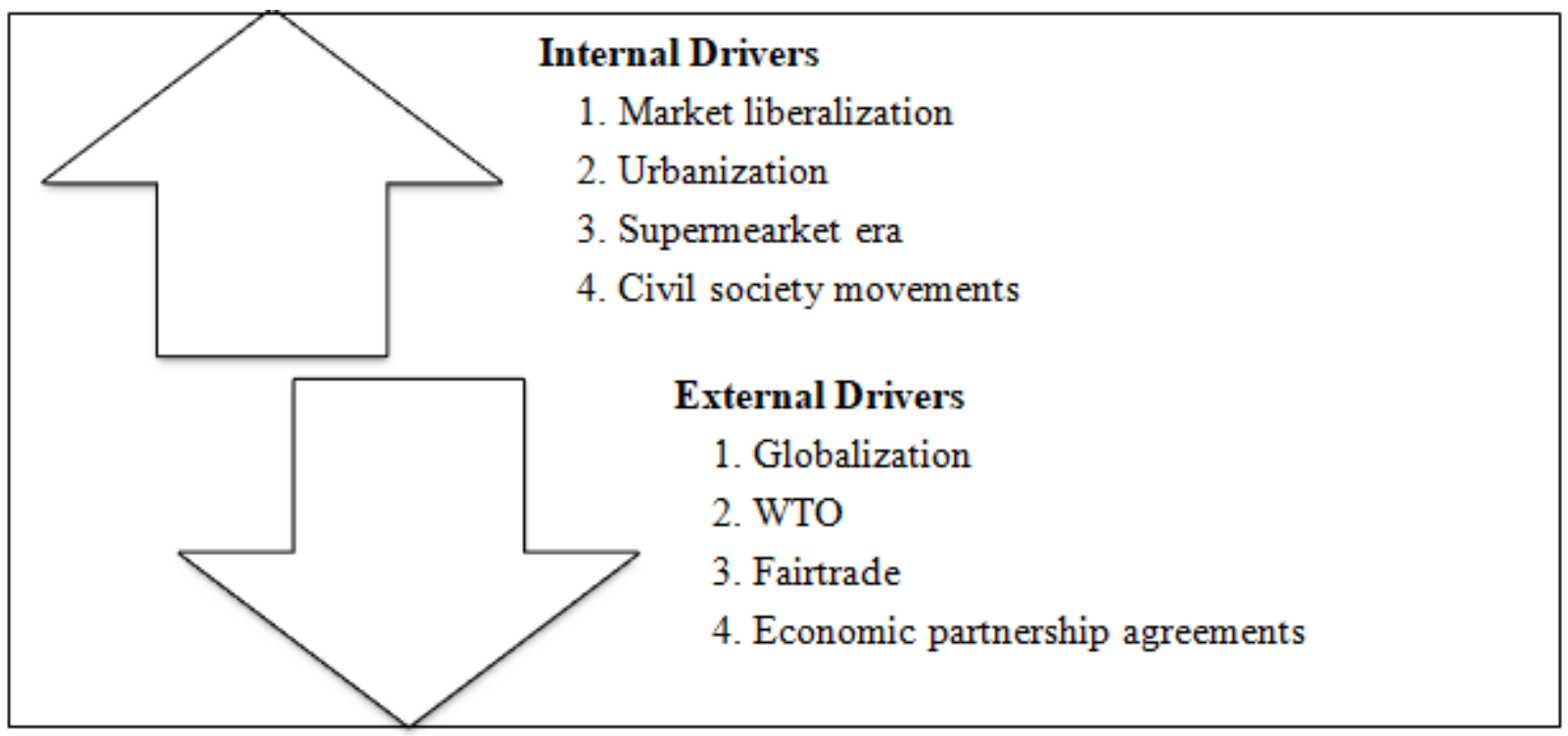

Source: http://111.93.2.168/idc/wp-content/uploads/2017/10/IDC-Report-5-AJ.pdf

However, the agricultural marketing system of the country suffered from many imperfections such as fragmented supply chain, huge postharvest losses, government controlled of wholesale markets, multiple food laws etc. As a result, government of India initiated reform measures in agricultural marketing system by the year 2001 .

\section{The Need for Reform 2003:}

1. APMC as independent entity: The system designed to protect farmers was in fact of very little use to farmers over the years as each APMC market yard functioned as an independent entity, not connected to any other markets. With each agriculture market acting as an independent entity, and despite earning substantial revenues from fees and taxes, the infrastructure in these APMC markets was scanty.

2. Restriction in Licensing: The entry of new traders was dependent on the existing market committee. So, the entry as a licensed agent was restricted, discouraging competition and encouraging cartelisation. The traders, commission agents and other functionaries organize themselves into associations which generally do not allow easy entry of new persons, contradicting the very spirit of competitive functioning

3. Fragmented and insufficient Markets: Each market functioned as a separate entity, hampering intra and interstate trade. At the same time, there were not enough markets to deal with growing produce. For example the area served per market yard is as high as 7096 Sq. Km in Sikkim, 1465 Sq. Km in Himachal Pradesh, 940 Sq. Km in Uttaranchal 
International Journal of Social Science and Economic Research

ISSN: $2455-8834$

Volume:06, Issue:05 "May 2021"

and 823 Sq. Km in Rajasthan. While National Commission on Agriculture, 1976 has recommended that a market should ideally cover at the most $80 \mathrm{sq} \mathrm{km}$ of area.

4. Market Fees \& Charges: There existed substantial variation in the rates of market fees among the States of India. The variation in respect of fee levied by some of the State governments is on higher side, leading to variation in prices resulting into to price differential across the country. For example, in Punjab, the total market charges on transactions of food grains were around $15.50 \%$. (market fee $2 \%$, Development charges $2 \%$, Purchase Tax 4\%, Commission charge - 2\%, Infrastructure cost $1.5 \%$, VAT $4 \%$ ad valorem apart from the charges for weighing - Rs.0.55, loading - R.0.40, Brokerage Rs.0.16, Hamal Rs.1 and cleaning 0.65/bag/qtl.) Commission charges in the market area varied between $2-5 \%$ in food grains and $4-8 \%$ in case of fruit and vegetables for different commodities across the States. There was a lack of uniformity in market fee across States. Multi-point levy of market fee in sales transactions leads to high marketing cost (GokulPatnaik, 2011).

5. Inadequate Infrastructure: Lack of infrastructures in general and regional variations in infrastructure, in particular, is the greatest barrier for evolving a common market in India. Studies reveal that the basic marketing infrastructure such as auction platform are there only in $2 / 3$ rd of the markets, drying platform in only $1 / 4$ th of the markets, grading facilities in $1 / 3 \mathrm{rd}$ of the markets, cold storages in only $9 \%$ of the markets etc. The incidence of huge post-harvest losses estimated by different studies at about $30 \%$ for fruits and vegetables, $7 \%$ for Food grains, $10 \%$ for spices can be attributed directly to absence of appropriate infrastructure only.

6. Post-Harvest Losses: This inadequate infrastructure led to high post-harvest losses, estimated at Rs. 90,000+ crores. This scenario is due to lack of private investments in the agriculture sector on account of long gestation and poor returns from the investment in market infrastructures .

7. High transaction Costs: Traditionally, a normal agricultural marketing chain in the country is fairly long with a large number of intermediaries between the producer and the consumer, adding more of costs than value. This reduces farmer's share in the consumer's rupee. As per different studies placed in the Millennium study of Ministry of Agriculture, it is $32-68 \%$ for fruit and vegetables, 56-89\% for paddy, 77-88\% for wheat, $72-86 \%$ for coarse grain and 79 to $86 \%$ for pulses. Marketing and costs and margins account for 30 to $35 \%$ of consumer's price in food grains, 45 to $55 \%$ in fruit and vegetables and 12 to $36 \%$ in oilseed crops. Statutory charges are assessed between 12 to 


\section{International Journal of Social Science and Economic Research}

ISSN: $2455-8834$

Volume:06, Issue:05 "May 2021"

$18 \%$ and net margins account for 15 to $30 \%$. Hidden marketing costs and margins are also common.

8. Information Asymmetry: Farmers access to market information is asymmetrical as against traders \& commission agents who are well informed. However, with advent of ICTs in the recent past, some section of the farmers are able to get real time market information, leaving large section of small and marginal farmers.

9. Fledgling rural markets: There are more than 21238 rural primary markets or periodic market places, which have remained outside ambit of development. These markets are the first contact point between the producer-sellers and the commercial circuit. Most of these markets lack even the basic amenities like drinking water, toilet, platforms etc. Provision of some minimum infrastructure in such market places and linking them with primary assembling markets will go a long way in the development of agricultural marketing system in the country. In the recent budget presented by Govt. of India has been earmarked for modernization of these markets.

10. Multiple food laws and absence of a common trade language: Different set of standards/specifications for agricultural commodities are followed by different organizations in the country. The standards laid down in the PFA Act are the National Standards. Besides this, there are AGMARK standards, BIS standards, standards followed by Army for procurement of its supplies, standards by warehousing corporations and those by Food Corporation of India for procurement purposes. Multiple food laws and regulators with multiple administering authorities at the central and the state level has led to inefficient management, often culminating in unnecessary harassment and distortion and in India's representation in the International forums. The traders of different commodities have got their own trade standards in different localities of the country. Thus, the absence of common trade language and a common food law is a major deterrent for evolving a common market in the country.

11. Controls under Essential commodities Act, 1955: Though central Government removed all restrictions on storage and movement of commodities, many state Governments still have different control orders promulgated under the EC Act adversely affecting trading in agricultural commodities such as food grains, edible oils, pulses and sugar etc. These control orders broadly relate to licensing of dealers, regulation of stock limits, restrictions on movement of goods, compulsory purchase under the system of levy. Due to the restrictive provisions of the Essential Commodities Act and various control orders issued there under, private investment in large scale storage and marketing has virtually become nonexistent. These control orders also give rise to rent-seeking by 


\section{International Journal of Social Science and Economic Research}

ISSN: $2455-8834$

Volume:06, Issue:05 "May 2021"

the enforcement functionaries at the border check points creating artificial barriers on the movement and storage of agricultural commodities and to that extent the formation of common market.

In view of constraints discussed above, the Government of India initiated reforms in agricultural marketing during 2003 with the following specific objectives:

$>$ To enhance farmers' market accessibility

$>$ To strengthen facilities/ infrastructure \& services of the existing organised marketing system under the APMC Act

$>$ To make the APMC markets efficient and professionally managed

$>$ To facilitate development of alternative marketing channels with the participation of private sector to create competition in services

$>$ To encourage both public \& private sector investment in development of post-harvest and marketing infrastructure

The matter of reforms in agricultural marketing had been under continuous scrutiny during the last two decades. On the recommendation of the Expert Committee of Agricultural Marketing (Government of India, 2001), the Inter-Ministerial Task Force (Government of India, 2002) recommended for formulation of Model Act 2003 for this purpose. Accordingly, the Department of Agriculture and Cooperation, Ministry of Agriculture, Government of India, in consultation with State Governments, trade and industry formulated a Model APMC Act 2003 and circulated it to the States during 2003 for its adoption.

The figure-2 gives a chronological picture the initiatives taken so far to motivate the states to amend their respective state APMR Acts and rules. The Road Map envisaged for the Model Act 2003 is as followed:

- Promote competitive agricultural markets in private and co-operative sector.

- Encourage Direct Marketing and Contract Farming programmes

- Promote dissemination of market information, grading and standardization by setting up a bureau for the purpose at state level

- Promote marketing extension by setting up a cell for the purpose at state level

- Facilitate procurement of agricultural produce directly from farmer's fields.

- Establish effective linkages between farm production and Retail Chains. 
- Facilitate Private Investment in owning, establishing and operating markets.

- Public-Private-Partnership to promote professionalism in existing markets.

- Stepping-up of Pledge Financing and Marketing Credit.

- Introduction of Negotiable Warehousing Receipt System in Rural Storage Projects.

- IT to Promote Trade and Market led Extension Services.

A separate Chapter were included with regard to legal issues in contract-farming arrangements in the country. It redefined the role of present Agricultural Produce Market Committee to promote alternative marketing systems like contract farming, direct marketing and farmers/consumers markets. It also redefined the role of State Agricultural Marketing Boards to promote standardization, grading, quality certification, market led extension and training of farmers and market functionaries in marketing related areas. Provision was also been made in the Act for constitution of State Agricultural Produce Marketing Standards Bureau for promotion of Grading, Standardization and Quality Certification of agricultural produce.

\section{Market reforms - Road travelled:}


International Journal of Social Science and Economic Research

ISSN: $2455-8834$

Volume:06, Issue:05 "May 2021"

Figure 2: Previous Reform Attempts

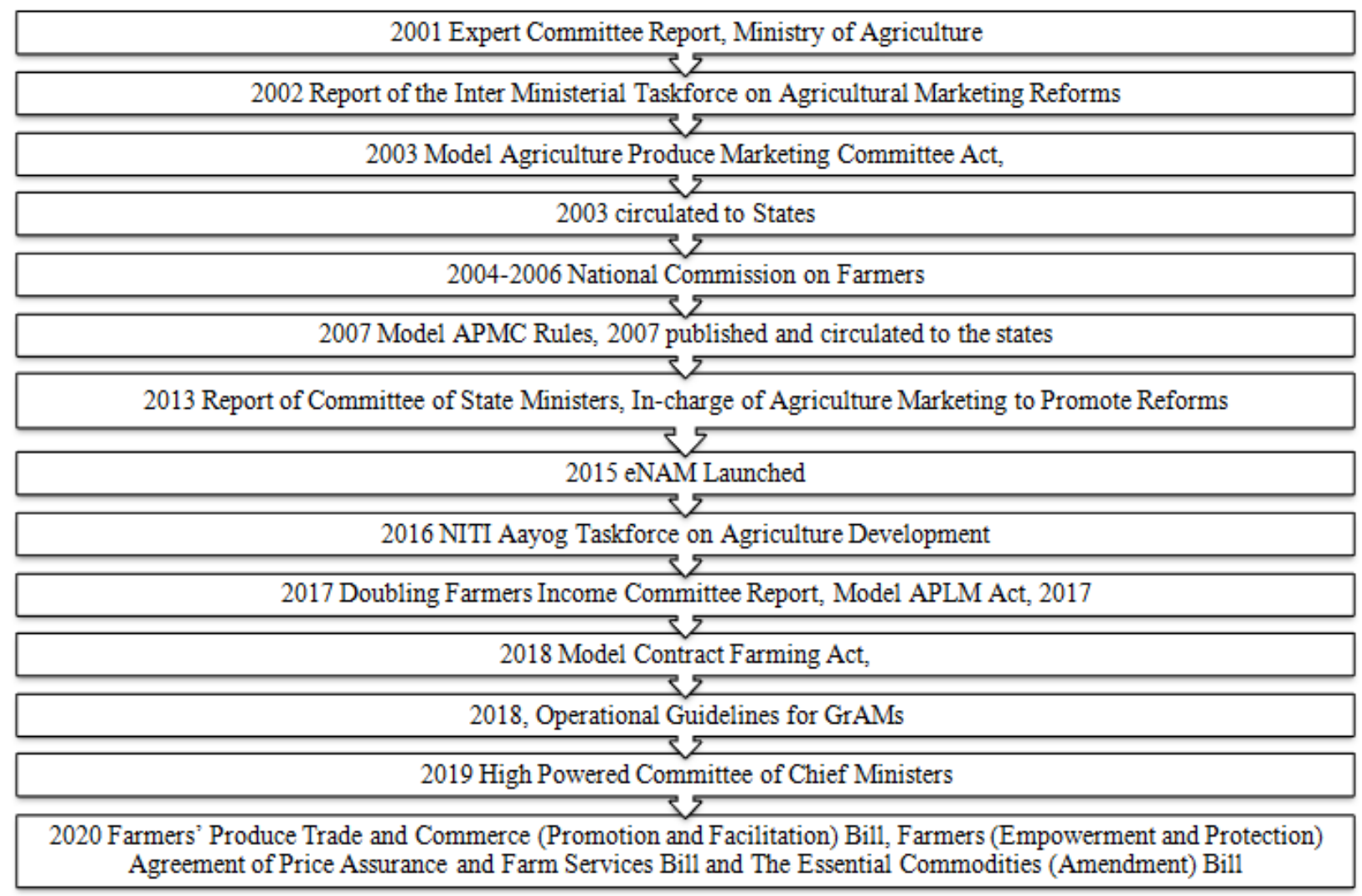

\section{Stock taking reforms of 2003:}

In spite of the efforts made by Govt. of India in motivating the states to adopt reforms, agricultural marketing being a state subject, and very few states came forward to adopt the provision of Model Act 2003. As a result, there was no uniformity in adoption of reforms envisaged in the Model Act, 2003.

Hence, Ministry of Agriculture, Government of India decided to set up an Empowered Committee of State Ministers in-charge of Agricultural Marketing. Accordingly, a committee under the chairmanship of __ was set up on $2^{\text {nd }}$ March, 2010 with an objective to encourage the states in the country to implement the reforms in the right sprit as envisaged in the Model Act, 2003 and Rules framed in the year 2007. The Committee in its report in 2011 (JaiprakashBisena and Ranjit Kumar, 2018) recommended for i)coherence of state APMC Acts and rules in line with Model Act and rule; ii) provision of multiple and competitive marketing channels to farmers; iii)integration of mandies with electronic spot exchange; iv) private investment in agricultural markets; v)infrastructure project status for agricultural markets; vi) waiving off of 
marketing fee on perishables like fruits and vegetables; vii) promotion of direct marketing as well as contract farming, etc. Several meetings were conducted by the committee to persuade the states in adopting the reforms. However, the adoption of Model Act, 2003 was not in the right spirit of provisions envisaged in it. The details are discussed as under:

Table 1: Status of Marketing Reforms with reference to 7 key areas vis-a-vis Model APMC Act, 2003 as on 31.03.2012.

\begin{tabular}{|c|c|c|}
\hline $\begin{array}{l}\text { Sl. } \\
\text { No. }\end{array}$ & Area of Reforms & $\begin{array}{l}\text { States adopted the suggested area of } \\
\text { marketing reforms }\end{array}$ \\
\hline 1 & $\begin{array}{l}\text { Establishment of private market yards/ } \\
\text { private markets managed by a person } \\
\text { other than a market committee. }\end{array}$ & $\begin{array}{l}\text { Andhra Pradesh, Arunachal Pradesh, Assam, } \\
\text { Chhattisgarh, Gujarat, Goa, Himachal Pradesh, } \\
\text { Karnataka, Maharashtra, Mizoram, Nagaland, } \\
\text { Orissa (excluding for paddy / rice), Rajasthan, } \\
\text { Sikkim, Telangana, Tripura, Punjab, UT of } \\
\text { Chandigarh, Jharkhand, Uttarakhand, West } \\
\text { Bengal. }\end{array}$ \\
\hline 2 & $\begin{array}{l}\text { Establishment of direct purchase of } \\
\text { agricultural produce from } \\
\text { agriculturist (Direct Purchasing from } \\
\text { producer) }\end{array}$ & $\begin{array}{l}\text { Andhra Pradesh, Arunachal Pradesh, Assam, } \\
\text { Chhattisgarh, Gujarat, Goa, Haryana (for } \\
\text { specified crop through establishment of } \\
\text { Collection Centres) Himachal Pradesh, } \\
\text { Karnataka, Madhya Pradesh, Maharashtra, } \\
\text { Mizoram, Nagaland, Rajasthan, Sikkim, } \\
\text { Telangana, Tripura, Punjab (only in Rule), UT of } \\
\text { Chandigarh (only in Rule), Jharkhand, } \\
\text { Uttarakhand and West Bengal. }\end{array}$ \\
\hline 3 & To promote and permit e-trading, & $\begin{array}{l}\text { Andhra Pradesh, Chhattisgarh, Gujarat, } \\
\text { Jharkhand, Haryana, H.P., Karnataka, Rajasthan, } \\
\text { Sikkim, Goa, Madhya Pradesh, Maharashtra } \\
\text { (has granted license to Commodity Exchanges } \\
\text { registered under FMC), Mizoram, Telangana, }\end{array}$ \\
\hline
\end{tabular}




\begin{tabular}{|c|c|c|}
\hline & & Uttarakhand . \\
\hline 4 & $\begin{array}{l}\text { Establishment of farmers/ consumers } \\
\text { market managed by a person other } \\
\text { than a market committee (Direct sale } \\
\text { by the producer) }\end{array}$ & $\begin{array}{l}\text { Arunachal Pradesh, Assam, Chhattisgarh, } \\
\text { Gujarat, Goa, Himachal Pradesh, Karnataka, } \\
\text { Maharashtra, Mizoram, Nagaland, Rajasthan, } \\
\text { Sikkim, Tripura, Jharkhand, Uttarakhand and } \\
\text { West Bengal. }\end{array}$ \\
\hline 5 & $\begin{array}{l}\text { Contract Farming Sponsor shall } \\
\text { register himself with the Marketing } \\
\text { Committee or with a prescribed } \\
\text { officer in such a manner as may be } \\
\text { prescribed. }\end{array}$ & $\begin{array}{l}\text { Andhra Pradesh, Arunachal Pradesh, Assam, } \\
\text { Chhattisgarh, Goa, Gujarat, Haryana Himachal } \\
\text { Pradesh, Jharkhand, Karnataka, Maharashtra, } \\
\text { Madhya Pradesh, Mizoram, Nagaland, Orissa, } \\
\text { Punjab (separate Act), Rajasthan, Sikkim, } \\
\text { Telangana, Tripura, Uttarakhand. }\end{array}$ \\
\hline 6 & Single point levy of market fee & $\begin{array}{l}\text { Andhra Pradesh, Rajasthan, Gujarat ( for } \\
\text { processor, grader, packer, value addition and } \\
\text { exporter), Goa, Himachal Pradesh, Chhattisgarh, } \\
\text { Karnataka, Madhya Pradesh, Nagaland, } \\
\text { Jharkhand, Sikkim, UT of Chandigarh, Punjab, } \\
\text { Mizoram, Telangana, Uttar Pradesh and } \\
\text { Uttarakhand. }\end{array}$ \\
\hline 7 & $\begin{array}{l}\text { Single registration/ license for trade/ } \\
\text { transaction in more than one market }\end{array}$ & $\begin{array}{l}\text { Andhra Pradesh, Goa, Gujarat, Haryana, } \\
\text { Himachal Pradesh, Karnataka (in Rules only), } \\
\text { Rajasthan, Chhattisgarh Madhya Pradesh, } \\
\text { Maharashtra, Mizoram Nagaland, Telangana ((in } \\
\text { Rules only), Sikkim. }\end{array}$ \\
\hline
\end{tabular}

Source:https://pib.gov.in/newsite/printrelease.aspx? relid=137359 
International Journal of Social Science and Economic Research

ISSN: $2455-8834$

Volume:06, Issue:05 "May 2021"

The table- reveals the position of different states in respect of different agricultural marketing reforms as suggested in the Model Act. Some states have violated the spirit of the reforms. The States of Andhra Pradesh, Arunachal Pradesh, Assam, Goa, Gujarat, Himachal Pradesh, Jharkhand, Karnataka, Maharashtra, Mizoram, Nagaland, Odisha, Rajasthan, Sikkim, Uttarakhand and Tripura (Source: DMI, Faridabad) have made this provision in the sense that they provided for minimum investment prescribed. Andhra Pradesh for eg., the license fee (Rs 50,000) and minimum investment for setting up of private market is Rs. 10 crores and discouraging for private/cooperative sector. Some states like Rajasthan and Maharashtra have provided that a private market can be set up only at particular distance form Government -owned APMCs, which is not in the spirit of inducing competition among public and private markets. Some states like HP and Rajasthan have authorized the Market Secretary of the local APMC as the registration authority for contract farming, which is undesirable, as contract-farming system is an alternative and a potential competitor to the state-owned APMCs. In Punjab and Chandigarh, there is an exemption of market fee for direct purchases of certain commodities by selected/identified processors. The States of Maharashtra, Gujarat and Karnataka have issued common license for direct procurement from farmers. Though setting up of private market is permitted in Orissa, but the periodicity of license has been limited for only three years. Such stipulations are likely to hamper private investment.

\section{Demand by the States}

In essence, the APMC Acts treated agriculture marketing as a localised subject, ensuring that the produce grown in the notified area was only allowed to be sold to traders within the notified area. Existing APMC Acts went to the extent of prohibiting end users and processors located elsewhere from buying directly from farmers, if they did not have a license with the respective APMC. The first recommendation made in the Report of Committee of State Ministers, Incharge of Agriculture Marketing to Promote Reforms, 2013 was that "States should amend their APMC Acts on the lines of the Model Act 2003". It also noted the slow pace and uneven nature of reforms undertaken by State Governments. The Committee also made the recommendation to "develop a National Single Market for agricultural produce, by removing all the existing physical, legal, and statutory barriers". It also recommended that a Central Legislation to deal with "Inter-State Agricultural Marketing, promotion of agribusiness, trade and commerce at the national level". The High Powered Committee of Chief Ministers for 'Transformation of Indian Agriculture', also recommended the creation of multiple marketing avenues for farmers, stressed the importance of contract farming \& amendments to the Essential Commodities Act. Therefore, it was clear that these reforms were in demand for a long while, with the demands coming from across party lines.

Towards One Nation, One Agriculture Market 
On the recommendations of the committee of State Ministers of Agricultural Marketing, Govt. of India introduced the concept of one nation one market. APMC Market yards will now face competition from other markets, prompting them to improve their own functioning if they want to stay relevant in this day and age. Farmers will no longer be bound to pay a long list of market fees, taxes, and cesses on their produce, thereby improving their returns. The development of infrastructure close to the farm gate will reduce post-harvest losses, improve remuneration through grading \& sorting and boost linkages to terminal markets in food processing, retail, and exports. This will also lead to the better price discovery mechanisms for farmers, leading to better remuneration for their produce. Transformation in agriculture marketing environment is all set to take place. The Central Sector Scheme for promotion of a National Agricultural Market (NAM) has been launched. A NAM can be realized through a pan-India electronic platform which can facilitate the participation of buyers and sellers from all over the country.

Key enablers to operationalize this platform are provision for material accounting, trade fulfilment, fund processing and post-sale document creation (like generation of e-bills) which would increase efficiency of intermediation. Generating e-permits for all transactions conducted on the platform would create an audit trail verifiable across the country and simplify movement of goods.

\section{e-NAM overview and progress:}

National Agriculture Market (eNAM) is a pan-India electronic trading portal which networks the existing APMC mandis to create a unified national market for agricultural commodities. Small Farmers Agribusiness Consortium (SFAC) is the lead agency for implementing eNAM under the aegis of Ministry of Agriculture and Farmers' Welfare, Government of India.

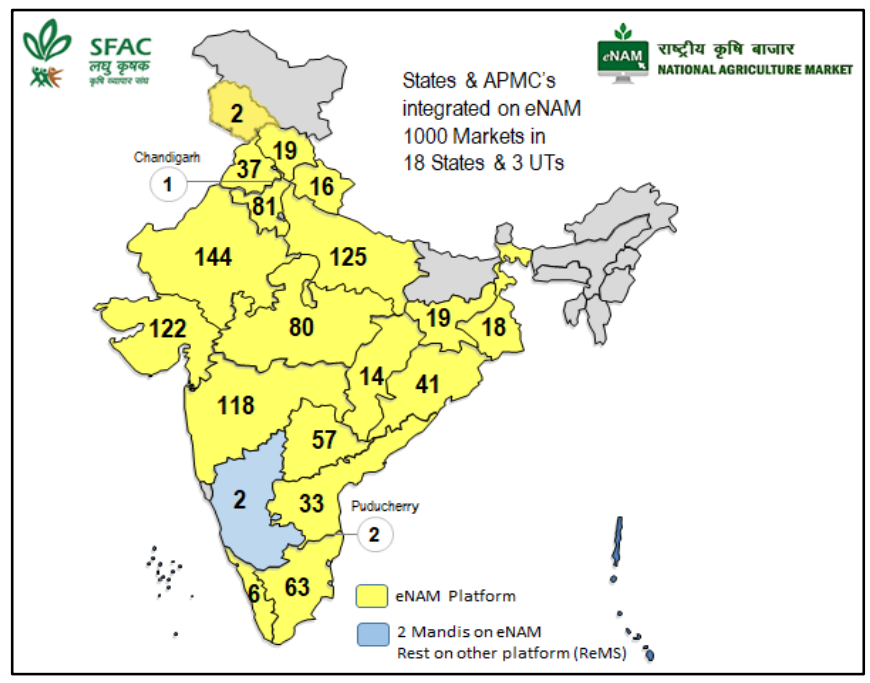

Source: https://enam.gov.in/web/enamcoverage 
International Journal of Social Science and Economic Research

ISSN: 2455-8834

Volume:06, Issue:05 "May 2021"

The e-NAM network was launched in August 2016 and about 585 mandis integrated with the eNAM in Phase 1 and 415 new mandis in Phase 2, the e-NAM platform now has a total number of 1,000 mandis across 18 States \& 3 UTs as of April, 2021. Around1,72,81,605 stakeholders including 1,70,25,393 famers, 1,63,391 traders, 90,980 commission agents (CAs) and 1,841 FPOs have been registered on e-NAM portal (www.enam.gov.in).

\section{Some key features that a NAM must have to realize the intended potential are:}

a) Auction of the produce takes place simultaneously in the same electronic platform in all regulated markets (APMC markets) in the country, as well as private markets as and when they come to be established.

b) Every regulated market is supported by infrastructure for quality assaying of the produce.

c) A buyer, irrespective of his location, can participate in any market of choice.

d) Collection of sale proceeds from the buyer and remitting it to the bank account of the seller is facilitated by the market.

e) Restrictions in transportation of the commodity are removed. This will come from the national Goods and Services Tax (GST) to support the movement of produce across state lines.

f) The required agri-logistics for storage and transportation is put in place.

g) The institution of agency to support inter-mandi trade, as also the dispute resolution mechanism are in place.

All above have been taken care of in the new Model Act (APLM 2017).

Model APLM Act, 2017:

In spite of several rounds of persuasion, the adoption of marketing reforms were not encouraging. Hence, Government of India came up with new set of reforms in the year 2017. As per New Model Agricultural Produce and Livestock Marketing (Promotion and Facilitation) Act, 2017, the new definition of market area, restricting the power of the market committee to enforce regulation in the principal market yards and submarkets yards only, is something in tune with the concept of unified market for agricultural produce. This concept was envisaged to pave way towards removing the entry barriers and trade barriers in the agricultural marketing system of the country. This makes marketing system more competitive by attracting new players and do away with the monopolistic and oligopolistic tendencies of the present players of the APMC markets. 


\section{International Journal of Social Science and Economic Research}

ISSN: $2455-8834$

Volume:06, Issue:05 "May 2021"

The inclusion of Livestock in the title of the new Model Act is a step in the right direction. In some of the states, the livestock and livestock products are not notified commodities. This will help in introducing good marketing practices even in the livestock sector. Hence states should amend their respective APMC Acts in line with the provisions of the New Model Act, 2017.

The new Model Act was enacted with the objective to end the monopoly of APMC and allow more players to set up markets and create competition, so that the farmers can readily discover prices their sale proceeds. The market fee caps under the new Model Act (including developmental and other charges) was prescribed at not more than 1 per cent for fruit and vegetables, and 2 per cent for foodgrain. It caps commission agents' fee at not more than 2 per cent for non-perishables and 4 per cent for perishables. This measure was intended to bring efficiency in supply chain and build a transparency in trade operations and an equitable environment for marketing. The new legislation also had a provision for promoting online or spot (e-national agriculture market) agriculture market platforms and ensure that all these measures are revenue neutral for States.

\section{The salient features of the Model APLM Act, 2017}

The Model APLM Act of 2017 aims at developing a state-level unified market through adoption of at least nine essential areas of reforms such as limiting regulation of APMC to within the physical premises of the mandi, separation of power and functions of marketing and managing director of the mandi board, declaring warehouses and cold storages as market sub-yards, deregulating fruits and vegetables, private markets, direct marketing and adhoc wholesale buying, e-trading, unified licence across the State and single point levy of market fee. The salient features of Model APLM Act, 2017 are listed below.

- The model APML act, 2017 is a comprehensive act for agri. produce, livestock, fisheries, etc. by creating a conducive environment to set up operative private wholesale market yards and farmer-consumer market yards, to enhance competition among different markets.

- It provides provisions for single point levy of market fee across the State and unified single trading license to realise cost-effective transactions.

- APLM provides recognition of a State/UT as a single market through abolition of fragmentation of market within the State/Union Territory (UT) by removing the conception of 'notified market area' in the regulation of Agricultural Produce and Livestock Market Committee (APLMC). 


\section{International Journal of Social Science and Economic Research}

ISSN: $2455-8834$

Volume:06, Issue:05 "May 2021"

- Besides, cereals, pulses and oilseeds, the Act provides geographical restriction-free trade transaction of agricultural produce including commercial crops like cotton, horticulture crops, livestock, fisheries and poultry.

- In this act there is a c complete democratization of Market Committee and State/UT Marketing Board and it has also granted provision for Special Commodity market yards and Market yards of National Importance (MNI).

- There is a clear separation of functions and powers between the Director of Agricultural Marketing and the Managing Director of State/UT Agricultural Marketing Board. The former is responsible for carrying out regulatory functions, while the latter would have to look after the developmental responsibilities under the Act.

- The act promotes disintermediation of food supply chain by the integration of farmers, exporters, processors, bulk retailers and consumers. It helps in promoting direct interface between farmers and processors/bulk-buyers/exporters/end users to reduce the price spread to benefit both producers and consumers.

- It enables declaration of warehouses/silos/cold storages and other structure/space as market sub-yard to provide better market access/linkages to farmers. And gives freedom to the agriculturalists to sell their produce to the buyers and at the place and time of their choice.

- It promotes a national market for agricultural produce through provisioning of an interstate trading license, grading and standardization and quality certification. The act also promotes e-trading to improve transparency in trade operations and integration of markets across geographies.

- It also has a provisions for single point levy of market fee across the State and unified single trading license to realise cost-effective transactions and rationalize market fee and commission charges.

\section{Model Contract Farming Act, 2018:}

Contract farming is billed to be a veritable instrument to address many of the traditional ills affecting the agriculture sector and the farmers, such as fragmentation of holdings, long chain of market intermediaries, ignorance about the requirements of the buyers, low farm mechanization, inadequacy of capital and distress sale and consequent heavy losses to farmers etc.

The smallholders participate and perform well within vertically integrated chains under contract farming, although wealthier farmers tend to dominate (Reardon et al., 2009). Theory suggests 


\section{International Journal of Social Science and Economic Research}

ISSN: $2455-8834$

Volume:06, Issue:05 "May 2021"

that transaction costs and investment constraints may lead to exclusion of smallholders from participating in contract farming. However, studies reveal that there is noteworthy participation of small holders in contract farming across the country (Swinnen and Maertens, 2007).

The history of contract farming goes back to 1920's, where ITC introduced cultivation of tobacco in Coastal AP. However, the modern contract farming started only during early 1990's with introduction of tomato cultivation by Pepsi. Besides, contract farming is practised in seed production, medicinal and aromatic plants.

Contact farming has been extended to non-crop activities also. Poultry farmers for both eggs and broilers function as a franchisee of larger enterprises in many States of the country particularly Tamil Nadu, Kerala, Karnataka and Andhra Pradesh. Of late, most of the food processing units are showing keen interest to enter into some form of contract supplies from producers. Food retail chains are also showing interest in backward integration through contract farming.

Several other studies also reveal that contract farming is an exciting way of giving the power of scale to the small farmers, of marrying the small farmer efficiency to the scale economy, transferring corporate management skills to the agriculture field, providing assured markets for the produce, reducing the transaction costs involved in the value chains of the commodities and of ensuring vertical integration through forward and backward linkages. Though contract farming is not a sole solution for problems in agricultural marketing, it can very well be leveraged for certain regions and crops for increasing farmers' income.

Under the Model APMC Act, 2003, contract farming was one of the alternative marketing system envisaged. The Agricultural Produce Marketing Committees (APMCs) were given the responsibility to record the contracts. They were also mandated to resolve the disputes in such contracts. However, market fee and other levies/charges were payable to APMCs.

In this regard, only 14 states have issued rules to govern contract farming. Despite this, it hasn't taken off properly and only 15 companies have entered into contract farming for crops in Punjab, Haryana, MP, Gujarat, Maharashtra, Karnataka and Chhattisgarh. Most of these contracts are for cotton and barley. It is clear that contract farming is not yet mainstream. Consequent to the Union Finance Minister's budget announcement, the Minister for Agriculture and Farmers' Welfare approved constitution of a Committee vide Order dated 28th February, 2017 to formulate a Model Contract Farming Act. The Committee comprising members from different departments / ministries of the Union Government and from select states, prepared a model provision called "The ___ State / Union Territory Agricultural Produce and Livestock Contract Farming (Promotion and Facilitation) Act, 2018, that would be a comprehensive, promotional facilitative and soft model law on contract farming. 
International Journal of Social Science and Economic Research

ISSN: 2455-8834

Volume:06, Issue:05 "May 2021"

Keeping in view of wide range of agriculture produce produced in the country, the Act includes all categories of agronomic \& horticultural crops, livestock, dairy, poultry and fishery. It further encompasses outputs that are both raw and primary processed in form.

\section{Salient features of Model Contract Farming Act, 2018 are:}

- The Act lays special emphasis on protecting the interests of the farmers, considering them as weaker of the two parties entering into a contract.(i)

- In addition to contract farming, services, contracts all along the value chain including pre-production, production and post-production have been included.

- "Registering and Agreement Recording Committee" or an "Officer" for the purpose at district/block/ taluka level for online registration of sponsor and recording of agreement provided.

- Contracted produce is to be covered under crop / livestock insurance in operation.

- Contract framing to be outside the ambit of APMC Act.

- No permanent structure can be developed on farmers' land/premises

- No right, title of interest of the land shall vest with the sponsor.

- Promotion of Farmer Producer Organization (FPOs) / Farmer Producer Companies (FPCs) to mobilize small and marginal farmers has been provided

- FPO/FPC can be a contracting party if so authorized by the farmers.

- Ensuring buying of entire pre-agreed quantity of one or more of agricultural produce, livestock or its product of contract farming producer as per contract.

- Contract Farming Facilitation Group (CFFG) for promoting contract farming and services at village / panchayat at level be provided.

- Accessible and simple dispute settlement mechanism at the lowest level possible provided for quick disposal of disputes.

- It is a promotional and facilitative Act and not regulatory in its structure

\section{Progress:}

All these set of reforms were again adopted by very few states, partially or fully. In fact, other reform measure during 2018 was initiated with regard to contract farming i.e., Model The --State /UT Agricultural Produce \& Livestock Contract Farming and Services (Promotion and 


\section{International Journal of Social Science and Economic Research}

ISSN: $2455-8834$

Volume:06, Issue:05 "May 2021"

facilitation Act), 2018. This reforms also could not see a light of the day. Only Tamil Nadu adopted this new Contract Farming Act.

The non-response of some of the states to implement provisions of different sets of reforms coupled with stress exerted by covid-19 pandemic, Government of India came up with three new set of reforms Viz., "The Farmers' Produce Trade and Commerce (Promotion and Facilitation) Act, 2020," "Farmers (Empowerment and Protection) Agreement on Price Assurance and Farm Services Act, 2020," "Essential Commodities (Amendment) Act, 2020."

The Farmers' Produce Trade and Commerce (Promotion \& Facilitation) Act, 2020"promulgated on June 5, 2020 which aims to provide for the creation of an ecosystem where farmers and traders enjoy freedom of choice relating to sale and purchase of farmers' produce and is expected to facilitate scientific price discovery through competitive alternative trading channels. It envisages promotion of efficient, transparent and barrier-free inter-State and intra-State trade and commerce of farmers' produce, outside the physical premises of markets or deemed markets notified under various State Agricultural Produce Market Legislations. It is a landmark reform giving the freedom of choice of sale and purchase of agricultural produce, as against the erstwhile setup in which farmers could only sell to licensed traders in the APMC mandis situated in close proximity and notified under various state agricultural produce market laws (state APMC Acts).

This Act has been introduced in order to effectively bypass the Agricultural Produce Market Committee (APMC) markets as it has been fraught with many challenges problems in different states such as lack of enough market yards, lack of facilities/amenities in the existing markets, the bureaucratic monopoly in existing APMC markets and aperiodic elections to the market committees, malpractices by traders such as non-issue of receipts, unwarranted deductions in the payments given to the farmers, etc.

On the other hand in few states, fake invoices were generated by the millers and an equivalent amount of produce were sourced from other states at a price lower than the minimum support price (MSP) announced by the government. This led to a situation where local farmers could not find adequate demand for their produce at MSP in the local market. Since most of the farmers are small or marginal landowners, they do not have wherewithal to transport their produce to large distances, and hence, are forced to sell them at a lower price than the MSP in the local market itself. The presence of all these inefficiencies and issues, however, does not mean that APMC markets are inherently problematic. APMC markets have been an important medium for price discovery at the local level for the farmers. Also for instance in a state like Bihar, the repeal of APMC Act in 2006 has neither helped the farmers in the state who have been forced to distress sale year after year well below the MSP nor has been able to ensure 


\section{International Journal of Social Science and Economic Research}

ISSN: $2455-8834$

Volume:06, Issue:05 "May 2021"

private investment in the development of market yards. Therefore, the need has been to reform the existing APMC markets and sub-markets in the rural areas, and also create newer ones in order to reduce the burden on the existing ones. Against this backdrop, the government of India promulgated the ordinance "The Farmers' Produce Trade and Commerce (Promotion \& Facilitation) Ct, 2020" on $5^{\text {th }}$ June, 2020.

Provisions of new ordinance on "The Farmers' Produce Trade and Commerce (Promotion \& Facilitation) Act, 2020"

1. Allows intra-state and inter-state trade of farmers' produce

2. Dispute resolution mechanisms

3. Trade in scheduled farmers' produce: An entity must be either: (i) a farmer producer organization or agricultural cooperative society, (ii) a person having permanent account number under the Income Tax Act or any other document notified by the central government.

4. Payment to farmers: Person transacting with a farmer will be required to make payments to the farmer on the same day, or within three working days in certain conditions, for any transaction of scheduled farmers' produce.

5. No fees to be levied by the states: The Ordinance prohibits the state governments from levying any market fee, cess or levy on farmers, traders, and electronic trading platforms for any trade under the Ordinance.

6. Permits electronic trading of farmers' produce in the specified trade area

The Farmers (Empowerment and Protection) Agreement on Price Assurance and Farm Services Act 2020"provides for a national framework on farming agreements that protects and empowers farmers to engage with agri-business firms, processors, wholesalers, exporters or large retailers for farm services and sale of prospective farming produce at mutually agreed remunerative prices. It provides a legal basis to the existing practice of contract farming in India's agriculture and allied sectors by providing a national framework for contract farming through ensuring uniformity across state regulations enacted under APMC Acts and the laws passed by some states on the lines of the model Act circulated in 2018. This Ordinance recognizes the freedom of farmers by enabling them to directly engage with sponsors of their choice, be it processors, aggregators, large retailers or exporters.

'The Farmers (Empowerment and Protection) Agreement on Price Assurance and Farm Services Act, 2020' that is designed to create a legal framework for contract farming in India 


\section{International Journal of Social Science and Economic Research}

ISSN: $2455-8834$

Volume:06, Issue:05 "May 2021"

seems to be the least contentious of the three ordinances. The ordinance rationales to protect the rights of farmers as well as sharecroppers.

\section{Provisions:}

1. Provisions of the Act will override all state APMC laws. Exemptions from all State Acts regulating sale/ purchase of farming produce and provisions of stock limits under ECA

2. Provides for a farming agreement prior to the production of any farm produce with individuals, partnership firms, companies, limited liability groups and societies.

3. The agreement may provide for mutually agreed terms and conditions for supply, quality, standards and price of farming produce as well as terms related to supply of farm services.

4. Pricing of farming produce: The price to be paid for the purchase of a farming produce will be mentioned in the agreement. In case of prices subjected to variations, the agreement must include: (i) a guaranteed price to be paid for such produce, and (ii) a clear reference for any additional amount over and above the guaranteed price, including bonus or premium. The price references may be linked to the prevailing prices or any other suitable benchmark prices. The method of determining any prices including guaranteed prices and additional amount will be provided in the farming agreement.

5. Dispute Settlement: The Act requires a farming agreement to provide for a conciliation board as well as a conciliation process for settlement of disputes. However, no action can be taken against the agricultural land of farmer for recovery of any dues.

6. Minimum period of an agreement will be one crop season, or one production cycle of livestock. The maximum period will be five years.

\section{Conclusion}

The recent liberalization, globalization and privatisation at global level and 1991 reforms initiated in the country have impacted Indian Agriculture. On account of these reforms, there is a cut throat competition in international market for agricultural commodities. On domestic front, the growth in industrial and service sector due to economic reforms of 1991 have resulted in increase in per capita income of middle class in the country. As a result, consumers are demanding for safe and nutritious food. To cope up with this situation, there is a need for diversification of crops and well developed marketing system. However, the regime of regulated marketing system suffered from several shortcomings. There was an attempt by Govt. of India, to initiate reforms in the agricultural marketing system in tune with the changes in economy 
International Journal of Social Science and Economic Research

ISSN: 2455-8834

Volume:06, Issue:05 "May 2021"

across the globe. However, the journey of agricultural marketing reforms as discussed in this article has revealed that there is a poor response from the state governments. Coupled with nonresponse of state governments and impact of COVID-19, the Govt. of India took a historic decision to introduce the new three farm Acts during 2020. The decision of the government has faced ire of some of the stakeholders in the systemic hindrance for free trade in agriculture.

\section{Reference}

Aggarwal, N., Jain, S. \& Narayanan, S. (2017). The long road to transformation of agricultural markets in India: lessons from Karnataka. Economic \& Political Weekly, 52 (41), 4755.

Chand, R. \& Singh, J. (2016). Agricultural marketing and farmer friendly reforms across Indian states and UTs. National Institute for Transforming India, NITI Aayog, New Delhi.

Chand, R. (2016). e-Platform for national agricultural market. Economics and Political Weekly, 51(28), 15- 18.

Chengappa, P.G., Arun, M., Yadava C.G. \&Prasanna Kumar, H.M. (2012). IT application in agricultural marketing service delivery - electronic tender system in regulated markets. Agricultural Economics Research Review, 25 (conference number), 359372.

Embassy of India, Phnom Penh. (2020). Agriculture Marketing Reforms in India: Fixing a Broken System. Available at: https://www.embindpp.gov.in/pdf/marquee/Agriculture Marketing Reforms in Indi a 2020 dec2 1.pdf

High Commission of India, Finland and Estonia (2020). Agriculture Marketing Reforms in India:

Fixing a Broken System. Available at: https://www.indembhelsinki.gov.in/pdf/AgriReforms_vF.pdf

High Commission of India, London, United Kingdom (2020). Agriculture Marketing Reforms in India: Fixing a Broken System. Available at: https://www.hcilondon.gov.in/docs/1606977121Agriculture\%20Marketing\%20Refor ms\%20in\%20India\%20Dec\%201.pdf

India International Centre. (2011). Status of Agricultural Marketing Reforms. IGIDR Proceedings/Projects Series. Available at: https://agritech.tnau.ac.in/amis/pdf/rs/Status Agrl Marketing Reforms.pdf 
Pavithra, S., Gracy, C P., Saxena R. \&Patil, G. G. (2018). Innovations in agricultural marketing: a case study of e-tendering system in Karnataka, India. Agricultural Economics Research Review, 31 (1), 53-64.

Rawal, V., Patel, S., \&Pais, J. (2020). The Political Economy of Agricultural Market Reforms. Society for Social and Economic Research. Available at: http://archive.indianstatistics.org/sserwp/sserwp2004.pdf

World Bank (2016). India's poverty profile. Available at: http://www.worldbank.org/en/ news/infographic/2016/ 05/27/india-s-poverty-profile. 